\title{
Risk factors associated with malnutrition in hospitalized patients
}

\author{
Fatores de risco associados à desnutrição \\ em pacientes hospitalizados
}

Roberta Flores Marquezini FRAGAS 1

Maria Conceição de OLIVEIRA²

A B S T R A C T

\section{Objective}

To identify factors associated with malnutrition in patients hospitalized in general public hospitals of the city of Manaus, Amazonas, Brazil.

\section{Methods}

This cross-sectional study included 397 patients of both sexes aged more than 18 years, staying at three public hospitals in Manaus, Amazonas. The patients were submitted to anthropometric and subjective global assessments, the latter being the main diagnostic method. For association analyses between malnutrition (dependent variable) and other covariates, we used contingency table for variable selection and multiple logistic regression for independent effect test between exposure and outcome. The strength of association between the variables was expressed as odds ratio, with a $95 \%$ confidence interval. The analyses were performed by Epi Info 7.0.

\section{Results}

Among the risk factors associated with hospital malnutrition, hospital stays longer than 15 days, when analyzed alone, nearly tripled the odds of malnutrition. However, in the final model, the variables that remained associated were: persistent change in diet, presence of gastrointestinal symptoms, recent weight loss, weight loss in the last six months, cancer, and age higher than 60 years.

\section{Conclusion}

Malnutrition is recurrent in hospitals, and the factors associated with malnutrition can be identified on admission, allowing adequate monitoring during hospital stay. Therefore, a more effective performance of nutritional screening and monitoring programs is critical.

Keywords: Inpatients. Malnutrition. Risk factors.

\footnotetext{
1 Instituto Federal de Educação, Ciência e Tecnologia do Amazonas, Setor de Saúde. Manaus, AM, Brasil.

2 Universidade Federal do Amazonas, Faculdade de Medicina, Departamento de Saúde Coletiva. R. Afonso Pena, 1053, Praça 14, 69025-050, Manaus, AM, Brasil. Correspondência para/Correspondence to: MC OLIVEIRA. E-mail: <olivmc@hotmail.com>. Article based on the marter's thesis of RFM FRAGAS, intitled "Prevalência da desnutrição em hospitais públicos de grande porte em Manaus - AM". Fundação Oswaldo Cruz; 2015.
} 


\section{R E S U M O}

\section{Objetivo}

Identificar fatores associados à desnutrição em pacientes internados em hospitais gerais da rede pública de Manaus, Amazonas.

\section{Métodos}

Estudo transversal que envolveu 397 pacientes, de ambos os sexos e idade superior a 18 anos, internados em três hospitais públicos de Manaus, Amazonas. Foi realizada avaliação antropométrica e avaliação subjetiva global, sendo esta última o método de diagnóstico principal. Para análises de associação entre desnutrição (variável dependente) e as demais covariáveis, foi realizado o teste Qui-quadrado para seleção das variáveis e regressão logística múltipla para teste de efeito independente entre exposição e desfecho. A força de associação entre as variáveis foi expressa em valores de odds ratio, com intervalo de confiança de $95 \%$. As análises foram realizadas por meio do programa Epi Info 7.0.

\section{Resultados}

Dentre os fatores de risco associados com desnutrição hospitalar, o tempo de internação superior a 15 dias, quando analisado isoladamente, quase triplicou a chance de o indivíduo desnutrir. Entretanto, no modelo final, as variáveis que mantiveram associação foram: mudança persistente na dieta; presença de sintomas gastrointestinais; perda de peso recente; e, nos últimos seis meses, câncer e idade superior a 60 anos.

\section{Conclusão}

A desnutrição é recorrente no meio hospitalar, e os fatores a ela associados podem ser identificados no momento da internação, o que permite um monitoramento adequado durante o período de hospitalização. Para tanto, torna-se imprescindivel a atuação mais efetiva de programas de triagem e acompanhamento nutricional.

Palavras-chave: Pacientes internados. Desnutrição. Fatores de risco.

\section{INTRODUCTION}

The primary causes of hospital malnutrition are the underlying disease and treatment complications. However, some isolated factors or their interaction can increase the risk of hospital malnutrition and consequent undesirable or fatal outcomes'.

In addition to the epidemiological or prepathogenic aspects stemming from exposures before hospital admission, risk factors increase during the disease period and are very common in the hospital environment because they are inherent to the disease, symptoms, and treatment ${ }^{2}$.

Among these risk factors, the hypercatabolic state provoked by conditions such as cancer or infectious diseases worsens nutritional status, as do long hospital stays, age higher than 60 years ${ }^{3,4}$, recent and involuntary weight loss ${ }^{5}$, changes in dietary consistency ${ }^{6}$, and gastrointestinal symptoms, such as nausea, dysphagia, abdominal pain, and anorexia, which somehow affect adequate food intake and nutrition.
Thus, it is critical to identify the risk factors associated with malnutrition on hospital admission to try to avoid or minimize the deleterious effects on patients' recovery ${ }^{7,8}$, given that hospital malnutrition is associated with longer hospital stays and higher incidence of infections and postoperative complications ${ }^{9}$, further burdening the public health system.

In this context, the objective of this study was to determine the variables associated with a higher risk of hospital malnutrition in patients staying at public hospitals of Manaus, Amazonas, Brazil.

\section{METHODS}

This is a secondary analysis of data from a quantitative epidemiological and hospital malnutrition study of three large general hospitals from the public health network of the city of Manaus (AM) from March to May 2014.

The eligibility criteria were: age equal to or greater than 18 years, either gender, and 
staying at the clinical, surgical, or intensive care wards of the hospitals. Individuals with plaster casts, submitted to limb amputations, or in clinical conditions that prevented anthropometric assessment were included in the study but only submitted to Subjective Global Assessment (SGA).

Pregnant or postnatal women and individuals with altered consciousness, unable to understand or communicate to answer the SGA questions and with no family member present to answer the questions were excluded.

The study included only the Sistema Único de Saúde general hospitals and emergency rooms with more than 150 beds that are directly managed by the Ministry of Health, Municipal Health Department, or State Health Department.

The researchers were trained for data collection, which included measuring height, weight, mid-upper arm circumference, physical examination, and filling out the study instrument. The SGA was performed by a single observer in order to minimize a possible diagnostic bias.

Body weight was measured by the portable bioimpedance scale Plenna Linea $\|^{\circledR}$ (Plenna Especialidades Ltda, São Paulo, Brazil) with maximum capacity of $150 \mathrm{~kg}$ and height by the portable stadiometer WCS ${ }^{\circledR}$ (Curitiba, Paraná, Brazil) with a total length of $220 \mathrm{~cm}$ and accuracy of one centimeter ${ }^{10,11}$. The Mid-Upper Dominant Arm Circumference (MUAC) was measured at the midpoint between the acromion and olecranon by an inelastic tape measure with the arm hanging by the side. The patients were assessed barefoot and with light clothing ${ }^{10}$.

The Body Mass Index (BMI) of all patients assessed by anthropometry was calculated ${ }^{10,12}$, and MUAC adequacy and classification relied on the cut-offs provided by Blackburn \& Thornton ${ }^{13}$. Nutritional status diagnosis was based on the SGA model systematized by Detsky et al..$^{14}$ and adapted by Waitzberg \& Ferrini ${ }^{15}$, classifying the individuals as well nourished, moderately malnourished, or severely malnourished.

Considering a 95\% Confidence Interval $(95 \% \mathrm{Cl})$, the sample size was calculated by the program Epi info 7.0 (Centers of Disease Control and Prevention, Atlanta, Georgia, United States), based on the number of beds in each hospital plus $10 \%$ to compensate for eventual losses. Additionally, the estimate considered the prevalence of hospital malnutrition reported in the literature, which varies from 30 to $60 \%{ }^{16,17}$, using a rough prevalence of $50 \%$, reported by the Inquérito Brasileiro de Avaliação Nutricional Hospitalar, conducted in $1996^{4}$.

The sample size of the hospitals was initially obtained by mapping bed distribution and numbering them sequentially from one to the total number of beds of each hospital. Next, to determine the interval between the study patients, the ratio of the sampled population and the total number of beds was calculated, resulting in a systematic sample.

The literature was reviewed to select the variables that could be associated with nutritional status. The study variables were: age $>60$ years; long hospital stay (>15 days); cancer; infection; gastrointestinal diagnosis; neurological diagnosis; gastrointestinal symptoms; weight loss in the last 6 months; current weight loss; and persistent dietary change.

Gastrointestinal symptoms were defined as the presence of one or more of the following self-reported complaints for more than 15 days: dysphagia and/or odynophagia, anorexia, abdominal pain or distention, nausea, vomiting, and diarrhea. Regarding the diet, changes in consistency (fluid/soft) or quantity lasting more than 30 days were defined as persistent dietary changes. These changes were taken into account whether they occurred at the hospital, as part of a diet therapy, or before hospitalization, when patients changed their diets because of inappetence or eating difficulties in order to adapt to their new health condition.

The Odds Ratio (OR) was calculated to quantify the strength of association between nutritional status and the study variables, using a contingency table or $2 \times 2$. 
Of the ten study variables, nine were included in the multiple logistic regression model because they were associated with malnutrition according to the Chi-square test, using as cut-off a $p$-value $\leq 0.20$ or a $20 \%$ probability of error of the variable in question not being associated with malnutrition ${ }^{5}$. The strength of association between the variables in the final model was expressed as OR, with a $95 \% \mathrm{Cl}$. The analyses were performed by the program Epi Info 7.018.

The study was approved by the Research Ethics Committee of the Universidade Federal do Amazonas under Protocol n 517,835, on January 29, 2014, and all participants and their buddies signed an Informed Consent Form before enrollment.

\section{RE S U L T S}

Of the 400 study patients from the three hospitals, one refused to participate in the study and two missed the examinations. Therefore, 397 patients were included. The mean age was $53 \pm 20$ (18-95) years, and most were males (59.7\%).

A total of 140 patients (35.26\%) were malnourished according to the SGA. Of these, 128 (32.24\%) were mildly or moderately malnourished, and 12 (3.02\%) were severely malnourished.
Among the risk factors associated with hospital malnutrition, most of the study covariates were highly prevalent in the malnourished patients, and some degree of association with this outcome was demonstrated by the $\mathrm{OR}, 95 \% \mathrm{Cl}$, and $p$-value (Table 1).

The risk factors for hospital malnutrition with the highest associations were persistent dietary change and gastrointestinal symptoms, which were reported by most patients diagnosed with malnutrition.

Regarding the subjective global assessment, patients who reported involuntary weight loss in the last 6 months or those who reported current and continuous weight loss during the assessment were four times more likely to be malnourished than those who denied having had these occurrences.

The results also showed that older adults and individuals with more than 15 days of hospital stay were three times more likely to become malnourished than adults or those with fewer than 15 days of hospital stay.

Regarding the underlying disease, neurological disease doubled the chance of malnutrition compared with other medical diagnoses. Cancer patients were four times more likely to be malnourished, and infection was present in more than half of the malnourished individuals.

Table 1. Chi-square test of the variables possibly associated with malnutrition listed in decreasing Odds Ratio (OR). Manaus (AM), Brazil, 2014

\begin{tabular}{lccccc}
\hline Risk factors for malnutrition & Frequency & $\%$ & OR & $95 \% \mathrm{Cl}$ & $p$-value \\
\hline Persistent dietary changes & 80 & 57.1 & 47.42 & $20.83-107.94$ & 0.00000 \\
Gastrointestinal symptoms & 136 & 97.1 & 24.41 & $8.76-68.04$ & 0.00000 \\
Current weight loss & 103 & 73.5 & 4.41 & $2.80-6.93$ & 0.00000 \\
Weight loss in the last 6 months & 110 & 78.5 & 4.15 & $2.59-6.66$ & 0.00000 \\
Cancer & 10 & 7.1 & 3.86 & $1.29-11.53$ & 0.01321 \\
Long hospital stay $(>15$ days) & 76 & 54.3 & 2.96 & $1.93-4.57$ & 0.00000 \\
Age $>60$ years & 83 & 59.3 & 2.82 & $1.84-4.33$ & 0.00000 \\
Neurological diagnosis & 28 & 20.0 & 2.21 & $1.23-3.94$ & 0.00883 \\
Infection & 87 & 62.1 & 1.82 & $1.20-2.79$ & 0.00611 \\
Gastrointestinal diagnosis & 27 & 19.3 & 1.21 & $0.71-2.07$ & 0.49017 \\
\hline
\end{tabular}

Note: $95 \% \mathrm{Cl}:$ 95\% Confidence Interval. 
Table 2. Multiple logistic regression analysis of the variables associated with malnutrition at a significance level of $5 \%(p \leq 0.05)$ after the Chi-square test. Manaus (AM), Brazil, 2014.

\begin{tabular}{lccc}
\hline Risk factors for malnutrition & $\mathrm{OR}$ & $95 \% \mathrm{Cl}$ & $p$-value \\
\hline Persistent dietary changes $^{*}$ & 33.40 & $12.05-92.55$ & 0.0000 \\
Gastrointestinal symptoms $^{*}$ & 13.28 & $3.86-45.68$ & 0.0000 \\
Cancer $^{*}$ & 10.32 & $1.49-71.36$ & 0.0179 \\
Current weight loss $^{*}$ & 3.36 & $1.73-6.50$ & 0.0003 \\
Weight loss in the last 6 months* $^{*}$ & 2.77 & $1.40-5.45$ & 0.0032 \\
Age $>60$ years & 2.24 & $1.20-4.16$ & 0.0105 \\
Infection & 1.42 & $0.74-2.73$ & 0.2801 \\
Long hospital stay (>15 days) & 1.39 & $0.69-2.77$ & 0.3499 \\
Neurological diagnosis & 0.57 & $0.19-1.67$ & 0.3071 \\
\hline
\end{tabular}

Note: "Factors associated with malnutrition after multiple logistic regression according to their Odds Ratio (OR), 95\% Confidence Interval (95\% CI), and $p$-value.

In multivariate logistic regression (Table 2), the variables that remained associated were: persistent dietary change, gastrointestinal symptoms, cancer, current weight loss, weight loss in the last 6 months, and age $>60$ years.

Persistent dietary change was the most important variable for the risk of malnutrition.

\section{DISCUSSION}

The study frequency of malnutrition was very similar to that found by other Brazilian and foreign studies ${ }^{16,19,20}$, corroborating the statement that along the last four decades, the prevalence of malnutrition has remained high ${ }^{21}$, increasing the length of hospital stay and risk of death ${ }^{22}$.

Thus, it is very important to identify and monitor factors that possibly contribute to malnutrition during hospitalization in order to minimize complications.

Regarding long hospital stays, studies ${ }^{3,4}$ have shown that patients with more than 15 days of hospital stay were three times more likely to be malnourished $(\mathrm{OR}=3.09 ; 95 \% \mathrm{Cl}=2.55-3.74$; $p<0.05 ; \mathrm{OR}=3.00 ; 95 \% \mathrm{Cl}=2.61-3.45 ; p<0.05)$, corroborating the results from the Chi-square test, where length of hospital stay higher than 15 days tripled the odds of patients becoming malnourished compared with shorter hospital stays. However, in multivariate analysis this variable lost strength of association because other factors proved to be more important with respect to malnutrition.

Regarding these factors, multiple regression analysis identified predictive variables, that is, variables associated with malnutrition in the study sample.

The subjective global assessment proposed by Detsky et al. ${ }^{14}$, a method widely used in clinical practice, consists of an anamnesis about recent body weight changes, changes in dietary patterns, and gastrointestinal changes. Given the patients' observations regarding food intake, the main study risk factor was persistent dietary change, that is, a change maintained for more than 30 days. Ferreira et al. ${ }^{23}$ found that decreased food intake is frequently observed in hospitalized patients, which can be related to dissatisfaction with hospital food and disease symptoms. According to Waitzberg et al. ${ }^{24}$, clinical symptoms like diarrhea, nausea, vomiting, and dysphagia generally lead to loss of appetite, food refusal, or food intake difficulties, which can contribute to nutritional status non-recovery or deterioration.

The presence of one or more gastrointestinal symptoms was reported by most of the study malnourished patients, which may somehow justify persistent dietary changes, whether in quantity, type, consistency, or frequency, and consequently, the high occurrence of current weight loss or weight loss in the last six months, given that inadequate food intake is one of the 
main causes of involuntary weight loss and malnutrition in hospitalized patients ${ }^{25}$.

Aquino \& Philippi $^{8}$ found that $62 \%$ of malnourished individuals reported changes in quantity, type, and consistency of the foods consumed secondary to the very frequent gastrointestinal changes, such as nausea, vomiting, and gastric changes. Consequently, the researchers found that recent and involuntary weight loss was the most important variable associated with risk of malnutrition ( $\mathrm{OR}=58.03 ; 95 \% \mathrm{Cl}=18.46-182.41$; $p<0.001)$. Hence, determining the influence of hospital food and the factors and symptoms that affect food intake and contribute to malnutrition in hospitalized patients may improve nutritional intervention actions and have a positive impact on length of hospital stay'.

In multivariate analysis gastrointestinal or neurological diseases did not remain associated with malnutrition in the study sample. Nonetheless, cancer patients were more likely to become malnourished than those with other diagnoses, which corroborates Waitzberg et al. ${ }^{4}$, who considered cancer a risk factor for malnutrition because they found that the frequency of malnutrition was three times higher in hospitalized patients with cancer.

Cancer patients' higher vulnerability is due to higher metabolic expenditure, protein deprivation caused by the tumor ${ }^{26}$, and the side effects of the treatment of choice. According to Ferreira et al. ${ }^{23}$, symptoms like anorexia, xerostomia, mucositis, and nausea are closely related to low acceptance of hospital food and consequently, with a higher risk of malnutrition.

Considering age as a risk factor for malnutrition, the results of this study corroborate results described elsewhere ${ }^{3,4}$, showing that changes associated with ageing promote changes in the nutritional requirements ${ }^{27}$. Older adults are a group at risk of malnutrition because of a number of morphological, motor, and sensory changes throughout the entire gastrointestinal tract, which has an important role in the regulation of appetite, satiety, and dietary pattern ${ }^{28}$.
The frequency data exposed in Table 1 also show that more than half of the malnourished individuals were older adults. Hence, given the high prevalence of malnutrition in older adults, Fidelix et al. ${ }^{29}$ reported the need of implementing strategies to identify, prevent, and treat this condition both in the hospital setting and after discharge.

One of the limitations of the method used is the reliance on the individual's memory and disposition to provide the necessary information for the association analyses. Additionally, it is important to note that the process of malnutrition is continuous and other variables may not have been considered because of the cross-sectional nature of the study, which prevents the inference of a cause-effect relationship.

\section{CONCLUSION}

The analyses suggest two important variables that deserve attention during hospitalization, persistent dietary changes and gastrointestinal symptoms. Generally, hospitalized patients need routine dietary follow-up between hospital routines and the identification of symptoms that may affect food acceptance, which can be easily determined by subjective assessment. Moreover, hospital admission should include body weight measurement and inquiries about recent weight loss.

Thorough knowledge about the current prevalence of malnutrition and the factors that contribute to nutritional status deterioration in hospitalized patients is critical in order to improve the quality and efficiency of nutritional care, given that it is a vital component for the patient's recovery.

\section{CONTRIBUTORS}

RFM FRAGAS conceived and designed the study, collected, analyzed, and interpreted the data, discussed the results, and wrote the manuscript under the supervision of MC OLIVEIRA. 


\section{REFERE N CES}

1. Leandro-Merhi VA, Srebernich SM, Gonçalves GMS, Aquino JLB. Perda de peso hospitalar, dieta prescrita e aceitação de alimentos. Arq Bras Cir Dig. 2015; 28(1):8-12. http://dx. doi.org/10.1590/S0102-67 202015000100003

2. Alencar MG, Leitao MB, Silva Prado LV. Evolução do estado nutricional de pacientes internados na clínica médica de um hospital filantrópico de Pernambuco - Brasil. Nutr Clín Diet Hosp. 2015; 35(3):8-16. http://dx.doi.org/10.12873/353

3. Correia MITD, Campos ACL. Prevalence of hospital malnutrition in Latin America: The multicenter ELAN study. Nutrition. 2003; 19(10):823-5. http://dx. doi. org/10.1016/S0899-9007(03)00168-0

4. Waitzberg DL, Caiaffa WT, Correia MITD. Hospital malnutrition: The Brazilian national survey (IBRANUTRI): A study of 4000 patients. Nutrition. 2001; 17(7):573-80. http://dx. doi.org/10.1016/S0 899-9007(01)00573-1

5. Aquino RC. Fatores associados ao risco de desnutrição e desenvolvimento de instrumentos de triagem nutricional [doutorado]. São Paulo: Universidade de São Paulo; 2005.

6. Ward J, Closet J, Little J, Boorman J, Perkins A, Coles SJ, et al. Development of a screening tool for assessing risk of undernutrition in patients in the community. J Hum Nutr Diet. 1998; 11(4):323-30.

7. Gouveia LAG, Oliveira A. Nutritional risk and associated factors in elderly patients with congestive heart failure in a Brazilian cardiology hospital. Rev Bras Geriatr Gerontol. 2014; 17(2):265-74.

8. Aquino RC, Philippi ST. Identificação de fatores de risco de desnutrição em pacientes internados. Rev Assoc Med Bras. 2011; 57(6):637-43.

9. Garcia RWD, Leandro-Merhi VA, Pereira AM. Estado nutricional e sua evolução em pacientes internados em clínica médica. Rev Bras Nutr Clín. 2004; 19(2):59-63.

10. World Health Organization. Physical status: The use and interpretation of anthropometry. Technical Report Series, n 854. Geneva: WHO; 1995.

11. Frisancho AR. New standards of weight and body composition by frame size and height for assessment of nutritional status of adults and the elderly. Am J Clin Nutr. 1984; 40:808-19.

12. Lipschitz DA. Screening for nutritional status in the elderly. Prim Care. 1994; 21(1):55-67.

13. Blackburn GL, Thornton PA. Nutritional assessment of the hospitalized patient. Med Clin North Am. 1979; 63(5):1103-15.
14. Detsky AS, Baker JP, O'Rourke K, Johnston N, Whitwell J, Mendelson RA, et al. Predicting nutrition-associated complications for patients undergoing gastrointestinal surgery. J Parenter Enteral Nutr. 1987; 11(5):440-6.

15. Waitzberg DL, Ferrini MT. Avaliação nutricional. In: Waitzberg DL. Nutrição enteral e parenteral na prática clínica. $2^{a}$ ed. São Paulo: Atheneu; 1995. p.127-52.

16. Garcia RS, Tavares LRC, Pastore CA. Nutritional screening in surgical patients of a teaching hospital from Southern Brazil: The impact of nutritional risk in clinical outcomes. Einstein. 2013; 11(2):147-52. http://dx.doi.org/10.1590/S1679-450820130002 00002

17. Rezende IFB, Oliveira VS, Kuwano EA, Leite APB, Rios I, Dórea YSS, et al. Prevalência da desnutrição hospitalar em pacientes internados em um hospital filantrópico em Salvador (BA), Brasil. Rev Ciênc Med Biol. 2004; 3(2):194-200.

18. Dean AG, Dean JA, Coulombier D, Brendel KA, Smith DC, Burton AH. Epi info: Version 7.0: A word processing database and statistics program for public health on IBM-compatible microcomputers. Atlanta: Centers of Disease Control and Prevention; 2014.

19. Marcadenti A, Vencatto C, Boucinha ME, Leuch MP, Rabello R, Londero LG. Desnutrição, tempo de internação e mortalidade em um hospital geral do Sul do Brasil. Rev Ciênc Saúde. 2011; 4(1):7-13.

20. Middleton MH, Nazarenko G, Nivison-Smith I, Smerdely P. Prevalence of malnutrition and 12 month incidence of mortality in two Sydney teaching hospitals. Int Med J. 2001; 31(8):455-61.

21. Corkins MR, Peggi G, DiMaria-Ghalili RA, Jensen GL, Malone A, Miller S, et al. Malnutrition diagnoses in hospitalized patients: United States, 2010. J Parenter Enteral Nutr. 2014; 38(2):186-95. http://dx.doi.org/ 10.1177/0148607113512154

22. Maicá AO, Schweigert ID. Avaliação nutricional em pacientes graves. Rev Bras Ter Intensiva. 2008; 20(3):286-95.

23. Ferreira D, Guimarães TG, Marcadenti A. Aceitação de dietas hospitalares e estado nutricional entre pacientes com câncer. Einstein. 2013; 11(1):41-6.

24. Waitzberg DL, Gama-Rodrigues J, Correia MITD. Desnutrição hospitalar no Brasil. In: Waitzberg DL. Nutrição oral, enteral e parenteral na prática clínica. São Paulo: Atheneu; 2002. p.385-97.

25. Kondrup J, Johansen N, Plum LM, Bak L, Larsen IH, Martinsen A, et al. Incidence of nutritional risk and causes of inadequate nutritional care in hospitals. 
Clin Nutr. 2002; 21(6):461-8. http://dx.doi.org/10. 1054/clnu.2002.0585

26. Poziomyck AK. Avaliação nutricional pré-operatória e risco cirúrgico em pacientes com tumores do trato gastrintestinal superior [mestrado]. Porto Alegre: Universidade Federal do Rio Grande do Sul; 2011.

27. Sousa VMC, Guariento ME. Avaliação do idoso desnutrido. Rev Bras Clin Med. 2009; 7(1):46-9.

28. Cebola MPABG. Malnutrição em idosos na admissão hospitalar: atuação perante a sua elevada pre- valência [doutorado]. Lisboa: Universidade Nova de Lisboa; 2014.

29. Fidelix MSP, Santana AFF, Gomes JR. Prevalência de desnutrição hospitalar em idosos. Rev Assoc Bras Nutr. 2013; 5(1):60-8.

Received: August 20, 2015

Final version: December 14, 2015

Approved: January 25, 2016 